\title{
A NEW URINARY MARKER FOR EARLY DETECTION OF ACUTE KIDNEY INJURY AFTER CARDIOPULMONARY BYPASSSURGERY IN PEDIATRIC PATIENTS
}

\author{
Shrook Ibrahim ${ }^{*}$, Sahar S. El-Sakka²,Waleed M.El-Guindy ${ }^{3}$, and Waleed M.Serag ${ }^{2}$ \\ ${ }^{1}$ Central Blood Bank, Ministry of Health and Population, Suez, Egypt. ${ }^{2}$ Chemistry Department, Faculty of Science, \\ Suez University, ${ }^{3}$ Faculty of Medicine, Ain Shams University,
}

\begin{abstract}
Acute kidney injury (AKI) signifies frequent complication after cardiac surgery using cardiopulmonary bypass (CPB). AKI raises the risk for prospective chronic kidney disease and renal failure, with its related mortality and morbidity. Traditional diagnostic approaches to AKI diagnosis such as changes in serum creatinine and blood urea was delayed by 2 to 3 days after CPB. Early detection of acute kidney injury (AKI) after cardiac surgery may improve patient's outcome, potentially reducing mortality, hospital length of stay, and costs. In the hope to enhance earlier more reliable characterization of AKI, we tested the utility of urine lipocalin biomarker in addition to standard creatinine and blood urea for early determination of AKI after cardiac surgery using CPB. Thirty patients were enrolled in the current study. 9 patients (30\%) developed AKI and 21 (70\%) did not (non-AKI group). Groups were comparable regarding demographics and surgical features. Serum creatinine and blood urea levels showed no statistical differences between the two groups at 2 hours after surgery and later on the first postoperative day. A significant elevation of creatinine and blood urea only observed in the group with AKI on the second post-operative day. Urinary lipocalin showed a highly significant difference between the two groups 2 hours after $C P B(P=<0.001)$ and later on the first postoperative day $(P<0.001)$. Elevated lipocalin levels significantly correlated with longer cardiopulmonary bypass, longer hospital stay, and death. From this study, it could be concluded that urinary lipocalin was a powerful predictor of acute kidney injury following CPB surgery.
\end{abstract}

Keywords: Lipocalin, Acute kidney injury, Cardiopulmonary bypass.

\section{INTRODUCTION}

Worldwide, more than 2 million cardiac surgeries are performed annually. Cardiac surgeryassociated acute kidney injury (CSA-AKI) is a candid postoperative complexity and is the second most frequent cause of AKI in the intensive care unit (Hilde R. H. de Geus et al, 2016). An incidence of CSA-AKI of up to $39 \%$ has been declared, varying depending on patient-related baseline characteristics and the type of surgery (Mao $\mathrm{H}$ et al, 2013). Between 3\% and 6.5\% all of surgical patients demand renal replacement medication. This worst stage of CSA-AKI is independently related with a very high mortality rate (Wald $\boldsymbol{R}$ et al, 2015). Other clinical consequences of CSA-AKI are represented in prolonged hospital stay, increased risk of chronic kidney disease (CKD), and increased risk of death after surgery (Hansen MK, 2013).

In current clinical practice, the gold standard for determination and categorization of AKI relies upon serial measurements of serum creatinine (Valerie $\mathrm{Au}$ et al, 2016). Unfortunately, Serum creatinine measurements are particularly unreliable during acute changes in kidney function as it has many inherent limitations (Jo SK et al, 2007). First, serum creatinine concentrations might not change until permanently $50 \%$ of kidney function has been lost. Second, serum creatinine does not properly reflect kidney function until a steady state has been reached, which could take several days. Finally, the serum levels of creatinine are affected by several non-renal factors such as age, gender, race, and muscular mass as well as factors such as drug metabolism, protein intake, perioperative fluid administration and hydration status (CR Parikh et al, 2006). All these reasons contribute to significant retards in the diagnosis of AKI.

As a result ofthe delayed response of creatinine and the deficiency of specific symptoms, AKI is often diagnosed late as well as an early specific therapy of intrinsic acute kidney injury is usually unavailable. On the other hand, creatinine often reflects chronic kidney disease rather than acute kidney injury. Because of these shortcomings of serum creatinine, more reliable biomarkers are needed for the diagnosis of acute kidney injury and provide prognostic information on outcomes once AKI is established (Siew et al, 2011). A desirable biomarker should be non-invasive, detectable at very early stages of 
acute damage, specific for cellular damage and prognostically relevant (Eugenia Singer et al, 2013). More recent studies on functional genomics and proteomics have identified possible renal biomarkers that are still under investigation and that may act as early markers of renal impairment. Among these, the most promising marker is lipocalin biomarker, a "real-time" urinary marker of tubular stress/injury (Haase $\boldsymbol{M}$ et al, 2011). Lipocalin-2 is a small $25-\mathrm{kD}$ peptide belonging to the lipocalin superfamily. It is normally expressed at very low levels in several human tissues, including kidney, lungs, stomach, and colon (Valeria Cernaro et al. 2016). Lipocalin-2 has been identified as the earliest and most robustly induced gene and protein in the kidney after ischemic or nephrotoxic injury and is easily measured in plasma or urine very early after injury (I.-C. Wang et al. 2016).

\section{MATERIALS AND METHODS}

This study was carried out as a cross-sectional study in Pediatric cardio surgery Academy, Ain Shams University hospital, it included 30 children patients who were suffering from congenital heart disease and undergoing cardiac surgery with cardiopulmonary bypass during the period from March 2015 to July 2015. All participants gave their informed written consent. The study populations ranging in age from 1 weak to 204 months, 19 of them were males and 11 were females. Two $\mathrm{ml}$ of blood samples were collected before surgery were used as the baseline, further sampling occurred at CPB termination, 2 hours after $\mathrm{CPB}$, on the first and second day after surgery. Creatinine and blood urea were analyzed using automated assay based on modified kinetic Jaffe reaction (Chemistry analyzer BTS310 from biosystems, Co. EU). Ten $\mathrm{ml}$ urine samples, for measurement of lipocalin, were collected before surgery were used as the baseline, further sampling occurred at CPB termination, 2 hours after $\mathrm{CPB}$, and on the first day after surgery. Urinary lipocalin biomarker measurement was performed using ELISA kit (Glory Science Co., Ltd: 2400 Veterans Blvd. Suite 16 - 101, Del Rio, TX 78840, USA) with $0.3 \mu \mathrm{g} / \mathrm{L}-7 \mu \mathrm{g} / \mathrm{L}$ detection range.

\section{Statistical analysis:}

Statistical analysis was performed using Statistical Program for Social Science (SPSS) version 20.0. Quantitative data were expressed as the mean \pm standard deviation (SD). Qualitative data were expressed as frequency and percentage. Independent-samples t-test of significance was used when comparing two means. Paired sample t-test of significance was used when comparing between related samples. Chi-square (X2) test of significance was used in order to compare proportions between two qualitative parameters. Receiver operating characteristic (ROC curve) analysis was used to find out the overall predictively of a parameter and to find out the best cut-off value with detection of sensitivity and specificity at this cut-off value.

\section{RESULTS}

Descriptive and comparative statistics of the demographic and laboratory data among AKI group and non-AKI group are included in table1.

The AKI group conducted into 9 patients while the non-AKI group conducted into 21 patients. There were $21(70 \%)$ children with Cyanotic congenital heart disease and $9(30 \%)$ children with acyanotic congenital heart disease. A significant increase in creatinine and blood urea in AKI group was delayed to the second day after CPB while, lipocalin increased significantly within 2 hours after surgery. Performanceof AKI markers that used in the present study are illustrated in table 2. Receiver operating characteristic (ROC) curve of serum creatinine levels at different time points after $\mathrm{CPB}$ are presented in figure 1. In this study, the ROC analysis showed the excellent diagnostic power of urinary lipocalin at $2 \mathrm{~h}$ post-CPB in predicting the future onset of AKI figure 2.

A significant association was found between urinary lipocalin at 2 hours and 24 hours after surgery and $\mathrm{CPB}$ time, operation time and hospital stay (Table 3). Furthermore, there were statistically significant correlations between urinary lipocalin at 2 hours and 24 hours post-surgery with the type of congenital heart defect (Table 4). Also, there were statistically significant correlations between urinary lipocalin at 2 hours and 24 hours post-surgery with death (Table 5). 
A NEW URINARY MARKER FOR EARLY DETECTION OF ACUTE KIDNEY INJURY

Table (1): Descriptive and comparative statistics of the demographic and laboratory data among AKI group and non-AKI group.

\begin{tabular}{|c|c|c|c|c|}
\hline parameters & $\begin{array}{c}\text { AKI } \\
\text { group }\end{array}$ & $\begin{array}{l}\text { Non-AKI } \\
\text { group }\end{array}$ & $t / Z / x^{2}$ & p-value \\
\hline $\begin{array}{l}\text { Age (months) } \\
\text { Median (IQR) } \\
\text { Range }\end{array}$ & $\begin{array}{c}12(14) \\
0.25-108\end{array}$ & $\begin{array}{c}24(67) \\
3-204\end{array}$ & -2.7 & $\begin{array}{l}0.006 \\
(\mathrm{~S})\end{array}$ \\
\hline $\begin{array}{l}\text { Sex [No. (\%)] } \\
\text { Male } \\
\text { Female }\end{array}$ & $\begin{array}{l}2(22.2 \%) \\
7(77.8 \%)\end{array}$ & $\begin{array}{c}9(42.9 \%) \\
12(57.1 \%)\end{array}$ & 1.1 & $\begin{array}{l}0.282 \\
(\mathrm{NS})\end{array}$ \\
\hline $\begin{array}{l}\text { Bypass time (min) } \\
\text { Mean } \pm \text { SD }\end{array}$ & $129.22 \pm 3.8$ & $68.86 \pm 13.5$ & 6.9 & $\begin{array}{l}<0.001 \\
\text { (HS) }\end{array}$ \\
\hline $\begin{array}{l}\text { Operation time (hr) } \\
\text { Mean } \pm \text { SD }\end{array}$ & $5.28 \pm 1.1$ & $3.10 \pm 0.3$ & 8.4 & $\begin{array}{l}<0.001 \\
\text { (HS) }\end{array}$ \\
\hline $\begin{array}{l}\text { Hospital stay (days) } \\
\text { Mean } \pm \text { SD }\end{array}$ & $11.22 \pm 3.4$ & $6.71 \pm 0.7$ & 5.7 & $\begin{array}{l}<0.001 \\
\text { (HS) }\end{array}$ \\
\hline $\begin{array}{l}\text { Serum creatinine at } \\
\text { baseline }(\mathrm{mg} / \mathrm{dl}) \mathrm{Mean} \pm \mathrm{SD}\end{array}$ & $0.60 \pm 0.1$ & $0.55 \pm 0.1$ & 0.9 & $\begin{array}{l}0.328 \\
(\mathrm{NS})\end{array}$ \\
\hline $\begin{array}{l}\text { Serum creatinine at } 2 \mathrm{hr} \\
(\mathrm{mg} / \mathrm{dl}) \text { Mean } \pm \text { SD }\end{array}$ & $0.87 \pm 0.1$ & $0.74 \pm 0.1$ & 1.9 & $\begin{array}{l}0.064 \\
(\mathrm{NS})\end{array}$ \\
\hline $\begin{array}{l}\text { Serum creatinine at } 24 \mathrm{hr} \\
(\mathrm{mg} / \mathrm{dl}) \text { Mean } \pm \text { SD }\end{array}$ & $0.9 \pm 0.2$ & $0.73 \pm 0.1$ & 1.4 & $\begin{array}{l}0.161 \\
(\mathrm{NS})\end{array}$ \\
\hline $\begin{array}{l}\text { Serum creatinine at } 48 \mathrm{hr} \\
(\mathrm{mg} / \mathrm{dl}) \mathrm{Mean} \pm \mathrm{SD}\end{array}$ & $1.67 \pm 0.1$ & $0.64 \pm 0.1$ & 20.8 & $\begin{array}{l}<0.001 \\
\text { (HS) }\end{array}$ \\
\hline $\begin{array}{l}\text { Baseline blood urea } \\
(\mathrm{mg} / \mathrm{dl}) \text { Mean } \pm \text { SD }\end{array}$ & $29.22 \pm 6.1$ & $25.00 \pm 6.4$ & 1.6 & $\begin{array}{l}0.109 \\
\text { (NS) }\end{array}$ \\
\hline $\begin{array}{l}\text { Blood urea at } 2 \mathrm{hr}(\mathrm{mg} / \mathrm{dl}) \\
\text { Mean } \pm \text { SD }\end{array}$ & $36.33 \pm 4.6$ & $30.29 \pm 6.4$ & 2.5 & $\begin{array}{l}0.118 \\
(\mathrm{NS})\end{array}$ \\
\hline $\begin{array}{l}\text { Blood urea at } 24 \mathrm{hr} \\
(\mathrm{mg} / \mathrm{dl}) \text { Mean } \pm \text { SD }\end{array}$ & $36.33 \pm 5.4$ & $29.52 \pm 5.9$ & 1.9 & $\begin{array}{r}0.064 \\
(\mathrm{NS})\end{array}$ \\
\hline $\begin{array}{l}\text { Blood urea at } 48 \text { hours } \\
(\mathrm{mg} / \mathrm{dl}) \text { Mean } \pm \text { SD }\end{array}$ & $51.78 \pm 2.8$ & $26.33 \pm 5.2$ & 13.6 & $\begin{array}{l}<0.001 \\
\text { (HS) }\end{array}$ \\
\hline $\begin{array}{l}\text { Lipocalin at } \\
\text { baseline(ng/ml) Mean } \pm \text { SD }\end{array}$ & $0.95 \pm 0.1$ & $0.98 \pm 0.1$ & -0.59 & $\begin{array}{l}0.557 \\
(\mathrm{NS})\end{array}$ \\
\hline $\begin{array}{l}\text { Lipocalin at } 2 \text { hr }(\mathrm{ng} / \mathrm{ml}) \\
\text { Mean } \pm \text { SD }\end{array}$ & $31.46 \pm 3.4$ & $1.73 \pm 0.4$ & 39.53 & $\begin{array}{l}<0.001 \\
\text { (HS) }\end{array}$ \\
\hline $\begin{array}{l}\text { Lipocalin at } 24 \mathrm{hr}(\mathrm{ng} / \mathrm{ml}) \\
\text { Mean } \pm \text { SD }\end{array}$ & $50.85 \pm 3.6$ & $2.59 \pm 0.6$ & 59.97 & $\begin{array}{l}<0.001 \\
\text { (HS) }\end{array}$ \\
\hline $\begin{array}{l}\text { Congenital heart defect } \\
\text { Cyanotic No. }(\%) \\
\text { Acyanotic No. }(\%)\end{array}$ & $\begin{array}{c}9(100 \%) \\
0(0 \%)\end{array}$ & $\begin{array}{c}12(57.1 \%) \\
9(42.9 \%)\end{array}$ & 5.510 & $\begin{array}{l}0.019 \\
(\mathrm{~S})\end{array}$ \\
\hline
\end{tabular}

Table (2): Sensitivity, specificity, and cutoffs of markers at 2 hours, 24 hours, and 48 hours after CPB surgery in discrimination of development of AKI.

\begin{tabular}{|l|c|c|c|c|c|c|}
\hline Marker levels & $\begin{array}{l}\text { Cutt- } \\
\text { off }\end{array}$ & Sensitivity & Specificity & + PV & -PV & AUC \\
\hline Creatinine (mg/dl) (2hr) & $>0.7$ & $55.5 \%$ & $52.3 \%$ & $33.3 \%$ & $73.3 \%$ & $56.6 \%$ \\
\hline Creatinine(mg/dl) (24hr) & $>0.8$ & $77.7 \%$ & $42.8 \%$ & $36.8 \%$ & $81.8 \%$ & $65.1 \%$ \\
\hline Creatinine(mg/dl) (48hr) & $>1$ & $88.9 \%$ & $100 \%$ & $100 \%$ & $95.5 \%$ & $97.4 \%$ \\
\hline Blood urea (mg/dl) (2hr) & $>28$ & $77.7 \%$ & $52.3 \%$ & $41.2 \%$ & $84.6 \%$ & $68.5 \%$ \\
\hline Blood urea (mg/dl) (24hr) & $>38$ & $33.3 \%$ & $71.4 \%$ & $33.3 \%$ & $71.4 \%$ & $67.7 \%$ \\
\hline Blood urea (mg/dl) (48hr) & $>35$ & $100 \%$ & $95.2 \%$ & $90 \%$ & $100 \%$ & $100 \%$ \\
\hline Lipocalin (ng/ml) (2hr) & $>2.8$ & $100 \%$ & $100 \%$ & $100 \%$ & $100 \%$ & $100 \%$ \\
\hline Lipocalin (ng/ml) (24hr) & $>3.9$ & $100 \%$ & $100 \%$ & $100 \%$ & $100 \%$ & $100 \%$ \\
\hline
\end{tabular}

Table (3):Correlation of lipocalin measurements (ng/ml) at baseline, $2 \mathrm{~h}$, and $24 \mathrm{~h}$ after CPB surgery with independent clinical factors in total patients.

\begin{tabular}{|c|c|c|c|c|c|c|}
\hline \multirow{2}{*}{ Comparison parameter } & \multicolumn{2}{|c|}{ 0 Hour } & \multicolumn{2}{c|}{ 2 Hour } & \multicolumn{2}{c|}{ 24 Hour } \\
\cline { 2 - 7 } & R & $\begin{array}{c}\text { P- } \\
\text { value }\end{array}$ & R & $\begin{array}{c}\text { P- } \\
\text { value }\end{array}$ & R & P-value \\
\hline Lipocalin versus Bypass time (min) & -0.142 & $\begin{array}{c}0.453 \\
\text { (NS) }\end{array}$ & 0.795 & $\begin{array}{c}0.000 \\
(\mathrm{HS})\end{array}$ & 0.819 & $\begin{array}{c}0.000 \\
\text { (HS) }\end{array}$ \\
\hline Lipocalin versus operation time(hr) & -0.313 & $\begin{array}{c}0.215 \\
\text { (NS) }\end{array}$ & 0.854 & $\begin{array}{c}0.000 \\
(\mathrm{HS})\end{array}$ & 0.876 & $\begin{array}{c}0.000 \\
\text { (HS) }\end{array}$ \\
\hline Lipocalin versus hospital stay (days) & -0.233 & $\begin{array}{c}0.093 \\
\text { (NS) }\end{array}$ & 0.758 & $\begin{array}{c}0.000 \\
(\mathrm{HS})\end{array}$ & 0.766 & $\begin{array}{c}0.000 \\
\text { (HS) }\end{array}$ \\
\hline
\end{tabular}


Table (4):Correlation of lipocalin measurements (ng/ml) at baseline, $2 \mathrm{~h}$, and $24 \mathrm{~h}$ after CPB surgery with the type of congenital heart defect.

\begin{tabular}{|l|c|c|c|c|c|c|}
\hline \multirow{2}{*}{$\begin{array}{c}\text { Lipocalin } \\
\text { measurements }\end{array}$} & \multicolumn{2}{|c|}{ Cyanotic } & \multicolumn{2}{c|}{ Acyanotic } & \multicolumn{2}{c|}{ t-test } \\
\cline { 2 - 7 } & Mean & \pm SD & Mean & \pm SD & t & p-value \\
\hline lipocalin 0h(ng/ml) & 0.99 & 0.13 & 0.92 & 0.04 & 1.47 & $\begin{array}{c}0.153 \\
(\mathbf{N S})\end{array}$ \\
\hline lipocalin 2h(ng/ml) & 14.41 & 15.30 & 1.88 & 0.48 & 2.43 & $\begin{array}{c}0.022 \\
\mathbf{( S )}\end{array}$ \\
\hline Lipocalin 24h(ng/ml) & 23.27 & 24.59 & 2.59 & 0.76 & 2.50 & $\begin{array}{c}0.019 \\
(\mathbf{S})\end{array}$ \\
\hline
\end{tabular}

Table (5):Correlation of lipocalin measurements $(\mathrm{ng} / \mathrm{ml})$ at baseline, $2 \mathrm{~h}$, and $24 \mathrm{~h}$ after CPB surgery with deaths

\begin{tabular}{|c|c|c|c|c|c|c|}
\hline \multirow{2}{*}{$\begin{array}{c}\text { Lipocalin } \\
\text { measurements }\end{array}$} & \multicolumn{2}{|c|}{ Death } & \multicolumn{2}{c|}{ Alive } & \multicolumn{2}{c|}{ t-test } \\
\cline { 2 - 7 } Mean & \pm SD & Mean & \pm SD & t & p-value \\
\hline Lipocalin 0h(ng/ml) & 0.85 & 0.01 & 0.98 & 0.12 & -1.95 & $\begin{array}{c}0.061 \\
(\mathbf{N S})\end{array}$ \\
\hline lipocalin 2h(ng/ml) & 33.47 & 2.33 & 8.12 & 12.28 & 3.51 & $\begin{array}{c}0.002 \\
(\mathbf{S})\end{array}$ \\
\hline lipocalin 24h(ng/ml) & 53.22 & 5.68 & 13.05 & 19.97 & 3.42 & $\begin{array}{c}0.002 \\
\mathbf{( S )}\end{array}$ \\
\hline
\end{tabular}

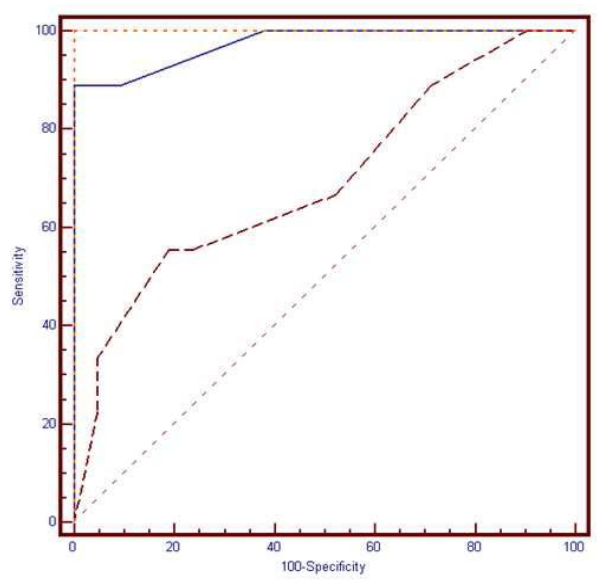

Figure (1): Receiver operating characteristic (ROC) curve of serum creatinine levels at $2 \mathrm{~h}, 24 \mathrm{~h}$, and $48 \mathrm{~h}$ after CPB for prediction of AKI. This figure shows that creatinine at $48 \mathrm{~h}$ postCPB could predict the development of AKI while creatinine at $2 \mathrm{~h}$ and $24 \mathrm{~h}$ fail to predict the development AKI.

Figure (2): Receiver operating characteristic (ROC) curve of urine lipocalin2 levels at 2 hours and 24 hours after CPB for prediction of AKI. Figure (18) show that lipocalin2 levels at 2 hours post-CPB could significantly and perfectly predict the development of AKI early after surgery.

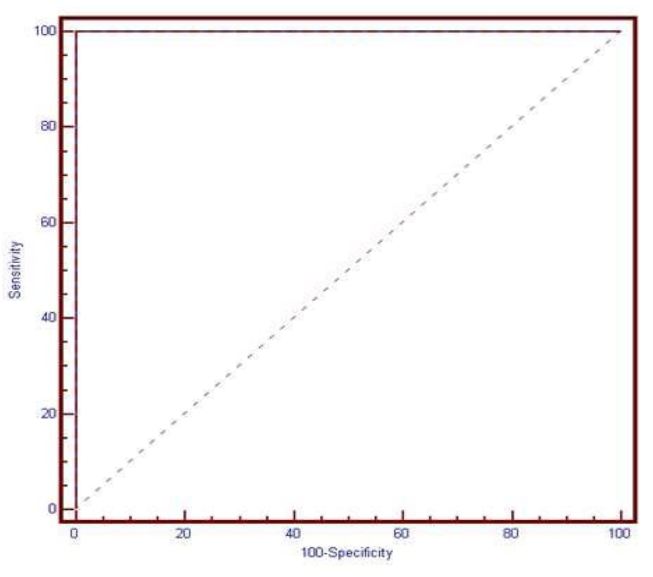


A NEW URINARY MARKER FOR EARLY DETECTION OF ACUTE KIDNEY INJURY 5 DISCUSSION

Similar results were documented in the study

In this study, the incidence of acute kidney injury in children following cardiopulmonary bypass surgery to be $30 \%$. This percentage is in broad agreement with the clinical study reported by Woo Sung Jang et al. (2014) which reported an incidence of $36.8 \%$. A higher incidence (50\%) of AKI after CPB surgery was reported in another clinical study by WesGabbard et al. (2010).

In our study creatinine was measured at different time intervals; 2 hours postoperative, 24 hours postoperative and 48 hours postoperative. This work was done to observe the performance of creatinine throughout two days after surgery. Serum creatinine was in normal range in all patients throughout 24 hours postoperative and shows a significant increase in AKI patients only 48 hours postoperative. That means, by using creatinine alone, AKI can only be detected 48 hours postoperative.

Comparing AKI group and non-AKI group, there was no statistically significant difference in creatinine level at 2 hours postoperative. Our results were comparable to the study done by Vishal Jain et al. (2016) where they found no statistically significant difference in creatinine level 2 hours postoperative.

In this study there was no statistically significant difference in creatinine level 24 hours postoperative Also, the study that was done by Elena Bignami et al (2015) on 19 patients undergoing cardiac surgery with cardiopulmonary bypass (CPB) demonstrated that there was no statistically significant difference between AKI and non-AKI patients according to SCr level 24 hours postoperative.

This study showed that SCr levels in AKI group $48 \mathrm{~h}$ post-operative ranged from 1.5-1.9 $\mathrm{mg} / \mathrm{dl}$ with a mean of $1.67 \pm 0.16 \mathrm{mg} / \mathrm{dl}$, while. S.cr levels in non-AKI group $48 \mathrm{~h}$ post-operative ranged from $0.5-0.9 \mathrm{mg} / \mathrm{dl}$ with a mean of $0.64 \pm 0.11 \mathrm{mg} / \mathrm{dl}$. A highly significant difference was noted between the two groups regarding $\mathrm{SCr}$ at $48 \mathrm{~h}$ post operation. The increase in serum creatinine was delayed by 2 days after $\mathrm{CPB}$ suggesting the presence of intrinsic AKI rather than a prerenal etiology. done by Michael Bennett et al. (2008). They found a highly significant difference between the two groups with respect to Serum creatinine 48 hours $(\mathrm{mg} / \mathrm{dl})$.

In the current study lipocalin levels increased in AKI patients very soon (2hours) after the procedure, and remained significantly elevated up to $24 \mathrm{~h}$ after the operation. Michael Bennett et al. (2008) showed similar findings of statistical significant of lipocalin measurement at $24 \mathrm{~h}$ after surgery like this current study results.

Biomarkers have a good discriminatory value if the AUC is greater than $75 \%$ and an excellent discriminatory value if the AUC is greater than 90 \% (Avinash B. Kumar and Manish Suneja, 2011). In this study, the ROC analysis showed the excellent diagnostic power of urinary lipocalin at 2 hours post-CPB in predicting the future onset of AKI (Table $3 \&$ figure 2). This finding was similar to the study of AmiraPeco-Antic et al. (2013) to assess the utility of urine lipocalin as a predictor of AKI and after weighting the AUCs, the timing of measurement, and the $\mathrm{p}$ values from the predictive logistic model they selected urine lipocalin as the perfect AKI predictor at 6 hours and 24 hours post-surgery. At 6 and $24 \mathrm{~h}$ after $\mathrm{CPB}$ the AUC was found for urine lipocalin to be ( 0.70 and 0.93 , respectively).

This study revealed that there was a strong significant direct correlation between urinary lipocalin and bypass time at 2 hours and 24 hours after surgery.Similar results were documented in the study that done by Catherine D et al. (2011). Their study showed that there was a strong significant direct correlation between urinary lipocalin and bypass time at 6 hours and 12 hours after surgery.

In the present study, age was significantly lower in children who developed AKI than in those who did not. This finding was in accordance with Mischel and Paulo (2013). Moreover, this study demonstrated that patients with cyanotic heart disease are more common to develop AKI after cardiopulmonary bypass surgery.In agreement, Sven Dittrich et al. (2000)demonstrated that patients with cyanotic heart disease have elevated risk to develop acute renal failure after cardiopulmonary bypass surgery. 
Shrook Ibrahim et al .,'

In the present study, a significant correlation was found between urine lipocalin levels at 2 hours and 24 hours after CPB surgery and death. Similar results were noted in the study that done by Bennett et al. (2008) on children undergoing CPB surgery. They found that elevated urine lipocalin levels correlated with mortality.

From this study, it could be concluded that AKI is common after pediatric CPB surgery and associated with poor outcomes. This study demonstrated that urinary lipocalin levels rose significantly in patients fulfilling the criteria for AKI much earlier as compared to serum creatinine in early hours after surgery. Such finding reflects the clinical utility of lipocalin for prediction AKI. Clinicians informed of such a situation would be aware of the potential for development of clinical AKI.The ability to predict which patients will develop AKI after CPB could enable early initiation of interventions to change the dismal outcomes associated with this all-toocommon clinical problem.

\section{REFERENCES}

1- AmiraPeco-Antić,IvanaIvanišević,IrenaVulićević,JelenaKotur-Stevuljević, Slobodan Ilić, JasminaIvanišević, MilicaMiljković, Nikola Kocev (2013): Biomarkers of acute kidney injury in pediatric cardiac surgery. Clinical Biochemistry, (46); 1244-1251.

2- Avinash B. Kumar and Manish Suneja (2011): Cardiopulmonary Bypass-associated Acute Kidney Injury. Anesthesiology; 114:964-70.

3- Catherine D. Krawczeski, Stuart L. Goldstein, Jessica G. Woo, Yu Wang, NuntawanPiyaphanee, MD, Michael Bennett, Prasad Devarajan (2011): Temporal Relationship and Predictive Value of Urinary Acute Kidney Injury Biomarkers After Pediatric Cardiopulmonary Bypass. Journal of the American College of Cardiology, 2301-9.

4- CR Parikh, J Mishra, H Thiessen-Philbrook, B Dursun, C Kelly, C Dent, P Devarajan and L Edelstein (2006): Urinary IL-18 is an early predictive biomarker of acute kidney injury after cardiac surgery. Kidney International; 70, 199-203.

5- Elena Bignami, Elena Frati, Roberta Meroni, Marco Simonini, AmbraLicia Di Prima, Paolo Manunta, Alberto Zangrillo (2015): Urinary neutrophil gelatinase-associated lipocalin time course during cardiac surgery. Annals of Cardiac Anaesthesia. Volume: 18, Issue : 1, Page : 39-44.

6- Eugenia Singer, LajosMarkó, Neal Paragas, Jonathan Barasch, DuskaDragun, Dominik N. Müller, Kl-
emensBudde, and Kai M. Schmidt-Ott (2013): Neutrophil gelatinase-associated lipocalin: pathophysiology and clinical applications. ActaPhysiol (Oxf); 207(4): 663-672.

7- Haase M, Haase-Fielitz A, Bellomo R, et al. (2011): Neutrophil gelatinase-associated lipocalin as a marker of acute renal disease.CurrOpinHematol; 18(1): 11-18.

8- Hansen MK, Gammelager H, Mikkelsen MM, Hjortdal VE, Layton JB, Johnsen SP, et al. (2013): Post-operative acute kidney injury and five-year risk of death, myocardial infarction, and stroke among elective cardiac surgical patients: a cohort study. Crit Care; 17:R292.

9- Hilde R. H. de Geus, Claudio Ronco, Michael Haase, Laurent Jacob, Andrew Lewington, and Jean-Louis Vincent (2016): The cardiac surgery-associated neutrophil gelatinase-associated lipocalin (CSA-NGAL) score: A potential tool to monitor acute tubular damage. The Journal of Thoracic and Cardiovascular Surgery; 151:1476-81.

10- I.-C. Wang, W.-L. Hsu, P.-H. Wu, H.-Y. Yin, H.-J. Tsai, and Y.-J. Lee (2016): Neutrophil Gelatinase-Associated Lipocalin in Cats with Naturally Occurring Chronic Kidney Disease. Journal of veterinary internal medicine, (31: 102).

11- Jo SK, Rosner MH, Okusa MD (2007): Pharmacologic treatment of acute kidney injury: Why drugs haven't worked and what is on the horizon. Clinical Journal of the American Society of NephrologyClin J Am SocNephrol2: 356-365. Joel A. Kaplan chapter 22.

12- Mao H, Katz N, Ariyanon W, Blanca-Martos L, Adybelli Z, Giuliani A, et al. (2013): Cardiac surgery-associated acute kidney injury. Cardiorenal Med; 3:178-99.

13- Michael Bennett, Catherine L. Dent, Qing Ma, SudhaDastrala, Frank Grenier, Ryan Workman, Hina Syed, Salman Ali, Jonathan Barasch, and Prasad Devarajan(2008): Urine NGAL Predicts Severity of Acute Kidney Injury After Cardiac Surgery. Clin J Am SocNephrol 3: 665-673.

14- Sven Dittrich, KatrinKurschat, Ingo Dahnert, Michael Vogel, Christian Muller, Vladimir Alexi-Meskishvili, Peter E. Lange (2000): Renal function after cardiopulmonary bypass surgery in cyanotic congenital heart disease.International Journal of Cardiology, (73) 173179.

15- Valeria Cernaro, DavideBolignano, Antoine Buemi, Antonio Lacquaniti, Domenico Santoro, and Michele Buemi (2016):Overview of Neutrophil GelatinaseAssociated Lipocalin (NGAL) as a Biomarker in Nephrology, book of Biomarkers in Kidney Disease chapter 10, Part of the series Biomarkers in Disease: Methods, Discoveries and Applicationspp 205-227.

16- Valerie Au, Justin Feit, Jonathan Barasch, Robert N. Sladen and Gebhard Wagener (2016): Urinary Neutrophil Gelatinase-Associated Lipocalin (NGAL) Distin- 
guishes Sustained From Transient Acute Kidney Injury after General Surgery. Kidney International Reports; 1, 3-9.

17- Vishal Jain, Yatin Mehta, Abhinav Gupta, Reetesh Sharma, ArunRaizada, NareshTrehan (2016): The role of neutrophil gelatinase-associated lipocalin in predicting acute kidney injury in patients undergoing off-pump coronary artery bypass graft: A pilot study. Ann Card Anaesth. 19(2): 225-230.

18- Wald R, McArthur E, Adhikari NK, Bagshaw SM, Burns KE, Garg AX, et al. (2015): Changing incidence and outcomes following dialysis-requiring acute kidney injury among critically ill adults: a population-based cohort study. Am J Kidney Dis; 65:870-7.

19- Wes Gabbard, Eric B Milbrandt and John A Kellum (2010): NGAL: an emerging tool for predicting severity of AKI is easily detected by a clinical assay. Critical Care, 14:318.

20- Woo Sung Jang, Woong-Han Kim, Kwangho Choi, JinHae Nam, JoonChul Jung, Bo Sang Kwon, GiBeom Kim, HeeGyung Kang, JeongRyul Lee, Yong Jin Kim (2014): Incidence, risk factors and clinical outcomes for acute kidney injury after aortic arch repair in paediatric patients.Eur J CardiothoracSurg; 45 (6): e208-e214.

\section{الليبوكالين البولى كمؤشر جديد للكثف المبكر لحدوث القصور الكلوى الحاد بعد عمليات القلب المفتوح فى الأطفال \\ شروق ابراهيم على' ,سحر السقا' ,وليد محمد الجندى",وليّ محمد سراج؟

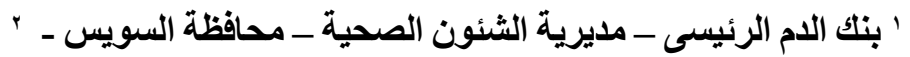

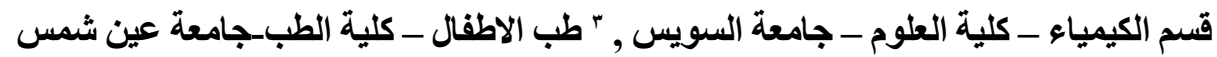

يعد القصور الكلوى الحاد من المضاعفات المتوقع حدوثها بعد عملية القلب المفتوح للأطفال وخاصة التى يستخدم فيها

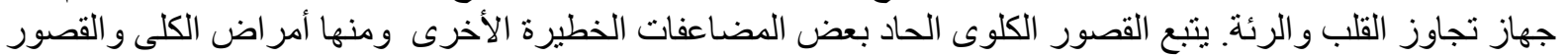

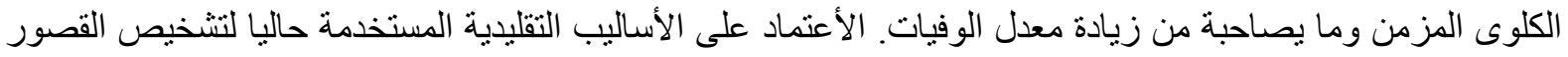

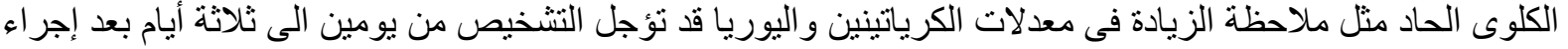

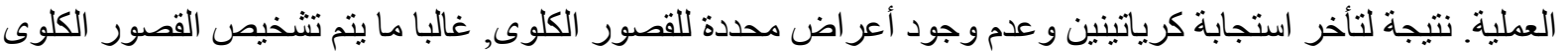

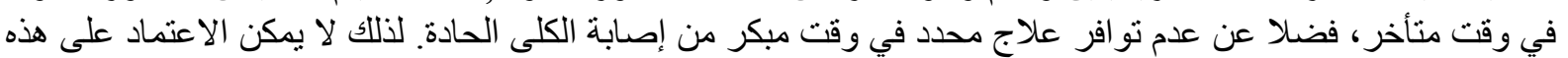

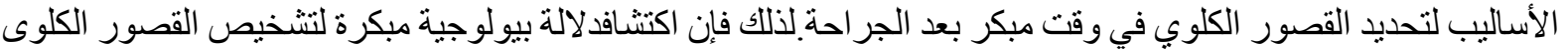

$$
\text { اصبح أمر ا ضروريا. }
$$

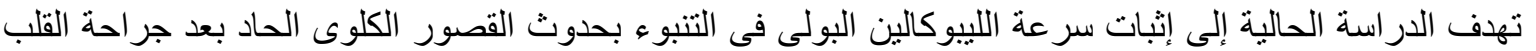

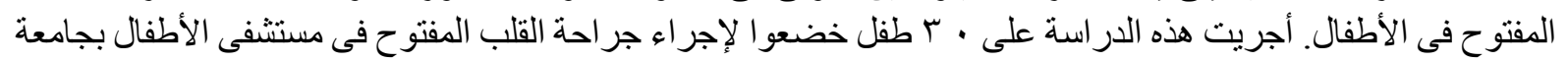
عين شمس. وقد تم تحليل عينات دم لمتابعة تركيز الكرياتينين و البوليناوعينات بول لالينال لمتابعة تركيز الليبوكالين. تم تقسيم

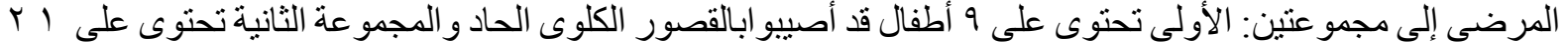

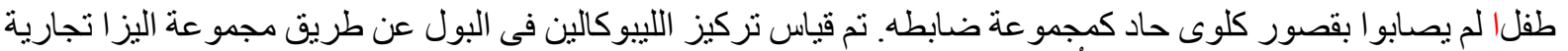

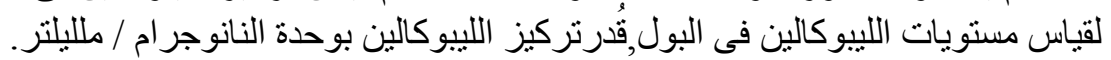

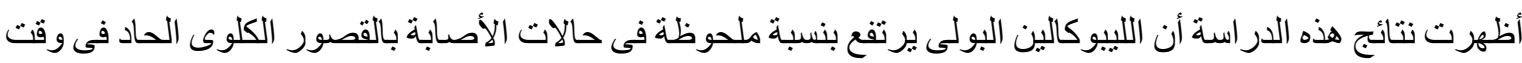

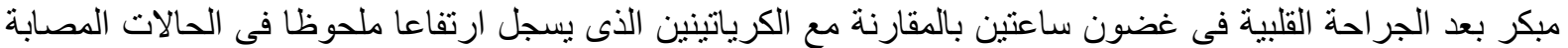

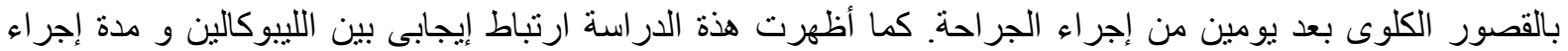

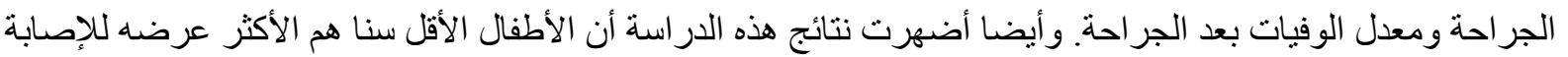

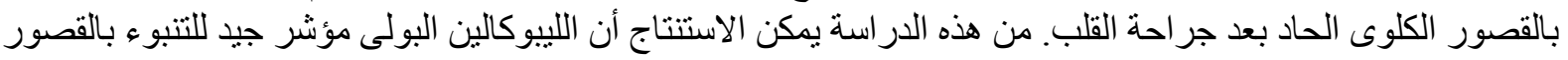
الكلوى الحاد فى وقت قياسى بعد حر اجة القلب المفتوح للأطفال. 